The $1^{\text {st }}$ Conf. of SSFOP "Future of Ornamental Plants in Egypt", Cairo, Egypt, 22/2/2015

Scientific J. Flowers \& Ornamental Plants

www.ssfop.com/journal

ISSN: 2356-7864

\title{
RESPONSE OF SEASHORE PASPALUM TURF TO SOME FERTILIZATION TREATMENTS
}

\author{
S.M. Shahin ; Boshra A. El-Sayed ${ }^{* *}$; T.M. Noor El-Deen ${ }^{* *}$ and Reem M. Said* \\ * Botanical Gardens Res. Dept., Hort. Res. Inst., ARC, Giza, Egypt. \\ ** Ornamental Plants and Landscape Gardening Res. Dept., Hort. Res. Inst., ARC, Giza, Egypt.
}

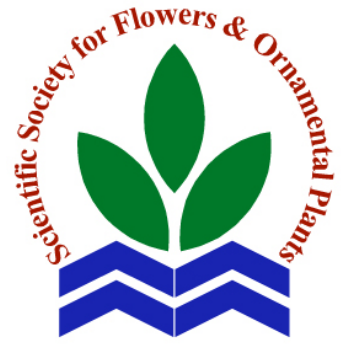

Scientific J. Flowers \& Ornamental Plants, 2(1):117-126 (2015).

Received:

$11 / 12 / 2014$

Revised by:

Prof. Dr. E.S. Nofal, Kafr El-Sheikh Univ.

Prof. Dr. M.M. Farahat, Agric. \& Biol. Res. Div., NRC.
ABSTRACT: A study was consummated in the open field at the Experimental Farm of Hort. Res. Inst., ARC, Giza, Egypt during 2013 and 2014 seasons to explore the response of seashore paspalum (Paspalum vaginatum Swartz) turf plants cultivated in $40-\mathrm{cm}$-diameter plastic pots filled with about $6 \mathrm{~kg}$ of sand and clay mixture $(1: 1, \mathrm{v} / \mathrm{v})$ to some fertilization treatments, viz., the humic acid liquid fertilizer at $20 \mathrm{ml} / \mathrm{l}$, as well as diatomite powder and the commercial complete fertilizer (NPK + micronutrients) at $1 \mathrm{~g} / \mathrm{l}$ for each, and also to the combined treatments between $20 \mathrm{ml} / 1$ humic acid and one of the abovenamed products at $1 \mathrm{~g} / 1$ for each, when applied with irrigation water (fertigation), five times with one month interval. The obtained results showed that all individual fertigation treatments significantly improved means of all vegetative growth traits over control ones in the two seasons, but the highest means were attained by humic acid, moringa leaf powder and the commercial complete fertilizer treatments which gave averages closely near together with non-significant differences among themselves in most cases of the two seasons. However, the least improvement was found due to the sole application of diatomite powder at $1 \mathrm{~g} / \mathrm{l}$. On the other side, the combining between humic acid $(20 \mathrm{ml} / \mathrm{l})$ and any one of the other fertilizers (at $1 \mathrm{~g} / \mathrm{l}$ for each) induced an additional improvement in all growth characters, with the prevalence of the connecting between humic acid at $20 \mathrm{ml} / 1$ and moringa leaf powder at $1 \mathrm{~g} / \mathrm{l}$, as such combination resulted the tallest plants, the highest No. plants/pot, the best coverage and the heaviest fresh and dry weights in most instances of both seasons. A similar trend was also observed as well regarding the content of chlorophyll a, b, carotenoids, N, $\mathrm{P}, \mathrm{K}$, total soluble sugars and total indoles. The opposite was the right concerning total phenols content, which was slightly affected by the most of individual and combined treatments applied in this study, except for $1 \mathrm{~g} / \mathrm{l}$ complete fertilizer treatment, alone or in combination with $20 \mathrm{ml} / 1$ humic acid one that elevated such component to the maximum values in the two seasons, as well as the combination of humic acid at $20 \mathrm{ml} / 1+$ moringa leaf powder at $1 \mathrm{~g} / \mathrm{l}$ that gave a contrary trend by reducing content of this constituent to the minimum values in both seasons.

So, it is advised to fertigate seashore paspalum turf grown in sand and clay mixture $(1: 1, \mathrm{v} / \mathrm{v})$ with humic acid liquid fertilizer at $20 \mathrm{ml} / 1$ plus moringa leaf powder at $1 \mathrm{~g} / \mathrm{l}$, five times with one month interval to get the best growth performance, density, colour and quality.

Key words: Seashore paspalum, Paspalum vaginatum Swartz, humic acid, diatomite powder, moringa leaf powder, fertilization treatments or fertigation, turfgrass. 


\section{S.M. Shahin et al.}

\section{INTRODUCTION}

Seashore paspalum (Paspalum vagimatum Swartz) is a succulent warm-season turf type grass that belongs to Fam. Gramineae, but it retains a healthy appearance all year-round, unlike bermudagrass that tends to go offcolour during cooler months and short days (Huxley et al., 1992). It is easily propagated by cuttings and pre-prepared rolls, and fast spreads with lateral growing stems called stolons. It makes an attractive perennial turf in tropical and subtropical areas and can tolerate irrigation water with high salinity levels, withstand mowing, treading as well as wear and tear (Morton, 1974).

Turfgrass plants usually undergo many stresses, i.e., they are crowded together and compete with each other for water and nutrients. They are regularly mowed and their clippings are often removed. So, they must be well fertilized to face these competition and the un-natural demands placed on them. With proper fertilization, the lawn will maintain good colour, density and vigour and will not easily succumb to insects, weeds or diseases (Peacock et al., 1985). There are many types of fertilizers handling now in our local market, among of them is humic acid or humates which provide soil microbs with energy, improve nutrients retention in the soil and enhance the water holding capacity (Dorer and Peacock, 1997). In this regard, El-Sayed (2012) reported that humic acid liquid fertilizer at $20 \mathrm{ml} / 1$ greatly improved height, covering rate and herb fresh and dry weights of seashore paspalum plants, besides increasing the leaf content of chlorophyll a, b, carotenoids, total soluble sugars, indoles and phenols. Similar observations were also revealed by AbdelFattah et al. (2008) on Tifway turf.

Diatomite powder prepared from one-cell Algae that their membranes are saturated with silica, i.e., silicon dioxide $\left(\mathrm{SiO}_{2}\right)$ is using now as a source for natural silica which provides the plants with energy and reinforces the plant's ability to protect itself against biotic and abiotic stresses, and soil treated with it will have optimal fertility through improving water physical and chemical properties and by allowing nutrients in the soil to remain available for plants. It can restores heavy metals and hydrocarbon-polluted areas and decreases mortality (Nathan and Morgan, 2009). On woody plants, Kozalowski and Davies (1975) mentioned that silica significantly reduced transpiration, with a positive effect on plant water potential.

The dry powder of moringa leaves (Moringa oleifera Lam.) are widely used for food, medication and industrial purposes and also for organic production of crops due to its content of proteins, fats, fibers, carbohydrates, amino acids, vitamins and minerals (Price, 2007). In a recent study, Moyo et al. (2011) found that the dried leaves of moringa contain the following minerals: $\mathrm{Ca}(3.65 \%), \mathrm{P}(0.3 \%)$, $\mathrm{Mg}(0.5 \%), \mathrm{K}(1.5 \%), \mathrm{Na}(0.17 \%), \mathrm{S}(0.63 \%)$, $\mathrm{Cu}$ (8.25\%), Fe (490 ppm), Zn (13.03 ppm), $\mathrm{Mn}(86.8 \mathrm{ppm})$ and Se (363 ppm). In this concern, Youssef and El-Sayed (2012) postulated that $1 \mathrm{~g} / \mathrm{l}$ of moringa extract as a foliar spray significantly improved vegetative and root growth of Euonymus japonicus cv. Aureus transplants and increased the content of chlorophyll a, b, carotenoids, total indoles and total phenols in the leaves. Furthermore, Khenizy et al. (2014) noticed that a holding solution containing moringa extract $(25 \%)+$ sucrose $(2 \%)+$ salicylic acid (150 ppm) increased flower longevity of Gypsophila paniculata cut flowers, as well as fresh weight $\%$, total carbohydrates $\%$ and water uptake, but decreased water loss, maintained quality rate, water balance and decreased No. of bacteria in the solution. On maize, Emmanuel et al. (2011) stated that cakes of moringa seeds increased the mineral content of the soil, and this in turn increased the yield.

The purpose of this study was to explore the effect of some fertilization treatments on growth and quality of seashore paspalum turf.

\section{MATERIAL AND METHODS}

A trial was performed in the open field at the Experimental Farm of Hort. Res. Inst., ARC, Giza, Egypt through 2013 and 2014 seasons in order to examine the role of some 
fertilization treatments on improving growth, density and color of paspalum sod.

Thus, circle pieces from pre-prepared rolles of seashore paspalum (Paspalum vaginatum Swartz) at a radius of $10 \mathrm{~cm}$ (their fresh weights ranged between 90-100 g) were carefully taken and planted on April, $1^{\text {st }}$ for each season in the center of 40-cm-diameter plastic pots (one piece/pot) filled with about $6 \mathrm{~kg}$ of an equal mixture of sand and clay. The physical and chemical analysis of the used sand and clay in the two seasons are shown in Table (1).

The pieces were gently pressed with hand to be more contact with the soil mixture and were then daily irrigated with about $300 \mathrm{ml}$ of a tap water/pot during the first 2 weeks after planting, while afterwards were irrigated 2 times a week with $400 \mathrm{ml}$ of water/pot till the end of experiment. After one month from planting (on first of May), the planted pieces received the following fertilization treatments with irrigation water (fertigation), monthly for 5 times till the first of September of each season:

1- No fertilization, referred to as control.

2- The humic acid liquid fertilizer (10 N:10 $\mathrm{P}_{2} \mathrm{O}_{5}: 10 \mathrm{~K}_{2} \mathrm{O}$ ) at the rate of $20 \mathrm{ml} / \mathrm{l}$.

3- The diatomite powder, as a source of natural silica $\left(\mathrm{SiO}_{2}\right)$ at the rate of $1 \mathrm{~g} / \mathrm{l}$.

4- The dried leaf powder of Moringa oleifera Lam. at the rate of $1 \mathrm{~g} / \mathrm{l}$.

5- The commercial complete fertilizer at the rate of $1 \mathrm{~g} / 1$.

6- The humic acid treatment was combined with each one of the other treatments to form the following 3 combinations:
a. Humic acid at $20 \mathrm{ml} / \mathrm{l}+$ diatomite powder at $1 \mathrm{~g} / 1$.
b. Humic acid at $20 \mathrm{ml} / \mathrm{l}+$ moringa leaf powder at $1 \mathrm{~g} / 1$.
c. Humic acid at $20 \mathrm{ml} / 1+$ commercial complete fertilizer at $1 \mathrm{~g} / 1$.

The main characteristics of humic acid fertilizer and chemical analysis of both dried leaf powder of moringa and commercial complete fertilizer are shown in Tables (2), (3) and (4), respectively. The pots were arranged for each season in a completely randomized design (Mead et al., 1993), with 3 replicates for each treatment, as each replicate contained 5 pots. All agricultural practices necessary for such plantation were carried out whenever needed.

The first cut was handly done after two months from planting (on June, $1^{\text {st }}$ ) using a very sharp stainless steel cutter leaving stubbles with 1 inch long. Other four cuts were monthly undertaken thereafter. Before each cut in the two seasons, plant height $(\mathrm{cm})$ was recorded, while number plants/pot and fresh and dry weights ( $\mathrm{g}$ ) of the resulted clippings after mowing were determined after each cut. Moreover, the covering rate as percentage was evaluated using the method described by Mahdi (1953). However, the means of each parameter abovenamed in the five taken cuts were collected and expressed in the tables as an average for all cuts. In fresh leaf samples taken from the last cut (on October, $1^{\text {st }}$ ), photosynthetic pigments (chlorophyll a, b and carotenoids, $\mathrm{mg} / \mathrm{g}$ f.w.), as well as total indoles and total phenols (mg/100 g f.w.) were measured according to the methods of Saric et al. (1967), A.O.A.C (1980) and William et al. (1965), respectively, while in dry samples, the percentages of nitrogen (Pregl, 1945), phosphorus (Cottenie at al., 1982), potassium (Jackson, 1973) and total soluble sugars (Dubois et al., 1956) were measured.

Data were then tabulated and subjected to analysis of variance using SAS Institute program (1994), according to Duncan's Multiple Range Test (Duncan, 1955), to detect the significancy among means of various treatments.

\section{RESULTS AND DISCUSSION}

\section{Effect of fertilization treatments on:}

\section{Vegetative growth parameters:}

Data presented in Tables (5 and 6) show that all individual fertilization treatments significantly improved all vegetative growth characters over control in the two seasons, but the best means were attained by humic acid, 
Table 1. The physical and chemical analyses of the used sand and clay during 2013 and 2014 seasons.

\begin{tabular}{|c|c|c|c|c|c|c|c|c|c|c|c|c|c|c|}
\hline \multirow{2}{*}{\multicolumn{2}{|c|}{ Soil type Seasons }} & \multicolumn{4}{|c|}{ Particle size distribution (\%) } & \multirow[b]{2}{*}{ S.P. pH } & \multirow{2}{*}{$\begin{array}{l}\text { E.C. } \\
(\mathbf{d S} / \mathrm{m})\end{array}$} & \multicolumn{4}{|c|}{ Cations (meq/l) } & \multicolumn{3}{|c|}{ Anions (meq/l) } \\
\hline & & $\begin{array}{c}\text { Coarse } \\
\text { sand }\end{array}$ & $\begin{array}{l}\text { Fine } \\
\text { sand }\end{array}$ & Silt & Clay & & & $\mathrm{Ca}^{++}$ & $\mathrm{Mg}^{++}$ & $\mathrm{Na}^{+}$ & $\mathbf{K}^{+}$ & $\mathrm{HCO}_{3}^{-}$ & $\mathrm{Cl}^{-}$ & $\mathrm{SO}_{4}^{--}$ \\
\hline \multirow{2}{*}{ Sand } & 2013 & 89.03 & 2.05 & 0.40 & 8.52 & 23.007 .92 & 3.72 & 7.50 & 1.63 & 33.60 & 0.50 & 3.20 & 22.00 & 18.03 \\
\hline & 2014 & 90.10 & 1.95 & 0.50 & 7.45 & 22.867 .89 & 3.75 & 19.42 & 8.33 & 7.20 & 0.75 & 1.60 & 7.00 & 27.10 \\
\hline \multirow{2}{*}{ Clay } & 2013 & 7.54 & 22.28 & 30.55 & 39.63 & 55.008 .17 & 2.26 & 7.82 & 2.12 & 15.40 & 0.75 & 6.60 & 8.20 & 11.29 \\
\hline & 2014 & 7.64 & 22.50 & 30.15 & 39.71 & 51.008 .09 & 2.38 & 7.50 & 2.20 & 15.50 & 0.75 & 6.78 & 8.02 & 11.15 \\
\hline
\end{tabular}

Table 2. Main characteristics of the liquid humic acid fertilizer used in both seasons.

\begin{tabular}{lclclc}
\hline Component & Value & Component & Value & Component & Value \\
\hline Humic acid (\%) & 2.90 & E.C. (dS/m) & 3.50 & B (ppm) & 70.0 \\
Organic matter /total solid (\%) & 42.51 & N (\%) & 10.00 & Fe (ppm) & 900.0 \\
Total HA / total solid (\%) & 65.80 & $\mathbf{P ~ ( \% )}$ & 10.00 & Mn (ppm) & 90.0 \\
Organic carbon (\%) & 24.64 & $\mathbf{K ~ ( \% )}$ & 10.00 & $\mathbf{Z n}(\mathbf{p p m )}$ & 90.0 \\
C/N ratio & 2.46 & $\mathbf{C a ~ ( \% )}$ & 0.06 & $\mathbf{C u}(\mathbf{p p m )}$ & 90.0 \\
pH & 8.20 & $\mathbf{M g}(\%)$ & 0.05 & $\mathbf{M o}(\mathbf{p p m})$ & Traces \\
\hline
\end{tabular}

Table 3. Chemical analysis of the dried leaf powder of Moringa oleifera Lam. used in the two seasons per 100 grams of dry matter (From Price, 2007).

\begin{tabular}{lclclc}
\hline Component & Value & Component & Value & Component & Value \\
\hline Moisture (\%) & 7.50 & Cu (mg) & 0.57 & Arginine (mg) & 1325 \\
Calories & 205 & Fe (mg) & 28.20 & Histidine (mg) & 613 \\
Protein (g) & 27.10 & S (mg) & 87.00 & Lysine (mg) & 1325 \\
Fat (g) & 2.30 & Oxalic acid (mg) & 1600 & Tryptephan (mg) & 425 \\
Carbohydrates (g) & 38.20 & Vit. A-B carotene (mg) & 16.30 & Phenylalanime (mg) & 1388 \\
Fiber & 19.20 & Vit.B1-thiamin (mg) & 2.64 & Methionine (mg) & 350 \\
Ca (mg) & 2.003 & Vit. B2-riboflavin (mg) & 20.50 & Threonine (mg) & 1188 \\
Mg (mg) & 368 & Vit. B3-nicotinic acid (mg) & 8.20 & Leucine (mg) & 1950 \\
P (mg) & 204 & Vit. C-ascorbic acid (mg) & 17.30 & Isoleucine (mg) & 825 \\
K (mg) & 1.33 & Vit. E. tocopherol acetata (mg) & 113 & Valine (mg) & 1063 \\
\hline *The B-carotene found in moringa is a precursor to retinol (Vit. A). & & & \\
\multicolumn{1}{r}{ There are about 25 rinds of B-carotene in moringa leaves. } & & &
\end{tabular}


Table 4. Chemical analysis of the commercial complete fertilizer used in the two seasons.

\begin{tabular}{lclclllc}
\hline Component & Value & Component & Value & Component & Value & Component & Value \\
\hline Total N (\%) & 22.00 & $\mathbf{C a}(\%)$ & 5.50 & $\mathbf{F e}(\%)$ & 0.05 & Mo (\%) & 0.002 \\
Available $\mathbf{P}_{\mathbf{2}} \mathbf{O}_{\mathbf{5}}(\%)$ & 5.00 & $\mathbf{M g}(\%)$ & 0.24 & $\mathbf{M n ~ ( \% )}$ & 0.07 & Citric acid (\%) & 0.50 \\
$\mathbf{K}_{\mathbf{2}} \mathbf{O}(\%)$ & 11.00 & $\mathbf{Z n}(\%)$ & 0.07 & $\mathbf{C u}(\%)$ & 0.05 & Sucrose (\%) & 0.30 \\
\hline
\end{tabular}

Table 5. Effect of fertilization treatments on plant height, number of plants/pot and covering rate of Paspalum vaginatum Swartz plants during 2013 and 2014 seasons.

\begin{tabular}{|c|c|c|c|c|c|c|}
\hline \multirow{2}{*}{ Treatments } & \multicolumn{2}{|c|}{ Plant height (cm) } & \multicolumn{2}{|c|}{ No. of plants/pot } & \multicolumn{2}{|c|}{ Covering rate (\%) } \\
\hline & 2013 & 2014 & 2013 & 2014 & 2013 & 2014 \\
\hline Control & $44.33 c$ & $43.60 \mathrm{~d}$ & $20.33 d$ & $21.33 \mathrm{~d}$ & $61.00 \mathrm{e}$ & $64.10 \mathrm{~d}$ \\
\hline $\mathrm{HA}$ at $20 \mathrm{ml} / \mathrm{l}(\mathrm{A})$ & $46.78 b$ & $49.17 \mathrm{~b}$ & $26.67 \mathrm{bc}$ & $28.33 b c$ & $80.10 \mathrm{c}$ & $85.00 \mathrm{bc}$ \\
\hline DP at $1 \mathrm{~g} / \mathrm{l}(\mathrm{B})$ & $45.10 \mathrm{c}$ & $47.25 \mathrm{c}$ & $23.33 \mathrm{c}$ & $25.00 \mathrm{c}$ & $69.89 \mathrm{~d}$ & $73.50 \mathrm{c}$ \\
\hline MLP at $1 \mathrm{~g} / \mathrm{l}(\mathrm{C})$ & $47.36 \mathrm{~b}$ & $49.73 b$ & $28.00 \mathrm{~b}$ & $30.00 \mathrm{~b}$ & $84.00 \mathrm{~b}$ & $88.33 b$ \\
\hline $\mathrm{CCF}$ at $1 \mathrm{~g} / \mathrm{l}$ (D) & $46.67 b$ & $49.03 b$ & $27.00 \mathrm{bc}$ & $28.36 \mathrm{bc}$ & $80.76 \mathrm{c}$ & $84.90 \mathrm{bc}$ \\
\hline $\mathbf{A}+\mathbf{B}$ & $46.93 b$ & $49.25 b$ & $27.82 b$ & $30.00 \mathrm{~b}$ & $83.50 \mathrm{~b}$ & $90.69 b$ \\
\hline $\mathbf{A}+\mathbf{C}$ & $50.00 \mathrm{a}$ & $52.67 \mathrm{a}$ & $32.00 \mathrm{a}$ & $35.61 \mathrm{a}$ & $100.00 \mathrm{a}$ & $100.00 \mathrm{a}$ \\
\hline $\mathbf{A}+\mathbf{D}$ & $48.79 \mathrm{ab}$ & $51.56 \mathrm{ab}$ & $32.00 \mathrm{a}$ & $33.96 \mathrm{ab}$ & $96.00 \mathrm{ab}$ & $98.47 \mathrm{a}$ \\
\hline
\end{tabular}

- HA = humic acid, DP = diatomite powder, MLP = moringa leaf powder and CCF $=$ commercial complete fertilizer.

- Means within a column having the same letters are not significantly different according to Duncan's Multiple Range Test (DMRT) at $5 \%$ level.

Table 6. Effect of fertilization treatments on fresh and dry weights of Paspalum vaginatum Swartz clippings/pot during 2013 and 2014 seasons.

\begin{tabular}{|c|c|c|c|c|}
\hline \multirow{2}{*}{ Treatments } & \multicolumn{2}{|c|}{ Fresh weight (g) } & \multicolumn{2}{|c|}{ Dry weight (g) } \\
\hline & 2013 & 2014 & 2013 & 2014 \\
\hline Control & $33.45 \mathrm{e}$ & $32.91 \mathrm{e}$ & $15.39 \mathrm{~d}$ & $15.09 \mathrm{~d}$ \\
\hline $\mathrm{HA}$ at $20 \mathrm{ml} / \mathrm{l}$ (A) & $58.50 \mathrm{bc}$ & $61.20 \mathrm{bc}$ & $22.78 b c$ & $23.81 \mathrm{bc}$ \\
\hline DP at $1 \mathrm{~g} / \mathrm{l}(\mathrm{B})$ & $41.75 \mathrm{~d}$ & $44.00 \mathrm{~d}$ & $20.15 \mathrm{c}$ & $21.26 \mathrm{c}$ \\
\hline MLP at $1 \mathrm{~g} / \mathrm{l}(\mathrm{C})$ & $60.33 b c$ & $63.10 \mathrm{~b}$ & $24.50 \mathrm{~b}$ & $25.07 \mathrm{~b}$ \\
\hline $\mathrm{CCF}$ at $1 \mathrm{~g} / \mathrm{l}$ (D) & $56.87 \mathrm{c}$ & $58.50 \mathrm{c}$ & $23.98 \mathrm{bc}$ & $24.68 \mathrm{bc}$ \\
\hline $\mathbf{A}+\mathbf{B}$ & $61.58 b$ & $64.33 b$ & $27.11 b$ & $29.00 \mathrm{~b}$ \\
\hline $\mathbf{A}+\mathbf{C}$ & $81.39 \mathrm{ab}$ & $87.30 \mathrm{a}$ & $38.76 \mathrm{a}$ & $41.62 \mathrm{a}$ \\
\hline 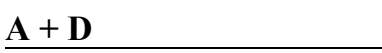 & $86.47 \mathrm{a}$ & $85.25 \mathrm{a}$ & $41.23 \mathrm{a}$ & $39.69 \mathrm{a}$ \\
\hline
\end{tabular}




\section{S.M. Shahin et al.}

moringa leaf powder and commercial complete fertilizer treatments which gave records closely near together with nonsignificant differences among themselves in most cases of both seasons. The least improvement, however was ascribed to the individual application of diatomite powder at 1 $\mathrm{g} / \mathrm{l}$. On the other hand, the combining between humic acid $(20 \mathrm{ml} / \mathrm{l})$ and the other fertilizers (1 $\mathrm{g} / \mathrm{l})$ caused an additional improvement in all growth parameters, with the superiority of the combined treatment between humic acid at 20 $\mathrm{ml} / \mathrm{l}$ and moringa leaf powder at $1 \mathrm{~g} / \mathrm{l}$ which gave, in general the tallest plants, the highest No. plants/pot, the best coverage and the heaviest fresh and dry weights in most instances of the two seasons and followed by the combination of $20 \mathrm{ml} / \mathrm{l} \mathrm{HA}+1 \mathrm{~g} / \mathrm{l}$ commercial complete fertilizer that gave records greatly near to those of the super combined treatment previously stated with non-significant differences among themselves in the $1^{\text {st }}$ and $2^{\text {nd }}$ seasons.

This may be attributed to lump the role of humic acid in increasing the availability of nutrients in the soil through influence on soil microbs activity, besides it contains NPK and some micronutrients necessary for good growth (Dorer and Peacock, 1997), and the role of either moringa leaf powder as a natural source of minerals, amino acids, vitamins and antioxidants (Price, 2007) or the complete fertilizer that contains different macro-and micro-nutrients in providing the plants with nutrients necessary for healthy growth.

The above results are supported by those obtained by El-Sayed (2012) on seashore paspalum, Abdel-Fattah et al. (2008) on Tifway sod, Youssef and El-Sayed (2012) on Euonymus japonicus cv. Aureus and Khenizy et al. (2014) on Gysophila paniculata.

\section{Chemical composition:}

It is clear from data averaged in Tables ( 7 , 8 and 9) that fertigation with both humic acid and other fertilizers, alone or in combinations induced significant increments in the leaf content of chlorophyll a, b and carotenoids (mg/g f.w.) and the percentages of N, P, K and total soluble sugars relative to their contents in the leaves of control plants with few exceptions in the two seasons. However, the least increasing in such components were registered by the sole fertigation with diatomite powder at $1 \mathrm{~g} / \mathrm{l}$, but the mastership in both seasons was for the combined treatments, especially between $20 \mathrm{ml} / 1$ humic acid and 1 $\mathrm{g} / \mathrm{l}$ moringa leaf powder, as such combination scored the utmost high content of the different constituents mentioned above and followed by the combination of $20 \mathrm{ml} / \mathrm{l} \mathrm{HA}+1 \mathrm{~g} / \mathrm{l}$ commercial complete fertilizer that gave means occupied the second rank. This may indicate the role of humic acid in enhancing the metabolic activity of soil microorganisms and acting as a source of $\mathrm{N}, \mathrm{P}, \mathrm{K}$ and $\mathrm{S}$ for plants (Higa and Wididana, 1991). Moreover, moringa leaf powder and complete fertilizer provide the plants with their requirements of minerals which activate biosynthesis processes in plant tissues.

A similar trend was also observed as well regarding the content of total indoles $(\mathrm{mg} / 100$ $\mathrm{g}$ f.w.), as it was significantly increased in response to the different sole or combined treatments employed in this work except for diatomite powder $(1 \mathrm{~g} / 1)$ treatment, to reach the maximum by combining between $\mathrm{HA}$ at 20 $\mathrm{ml} / \mathrm{l}$ and moringa leaf powder at $1 \mathrm{~g} / \mathrm{l}$ in the two seasons. The opposite was the right concerning total phenols content which was stable in most cases of both seasons, with the exception of $1 \mathrm{~g} / \mathrm{l}$ complete fertilizer treatment, alone or combined with $20 \mathrm{ml} / 1$ humic acid that elevated such component to the maximum values in the first and second seasons, as well as the combination of $20 \mathrm{ml} / \mathrm{l} \mathrm{HA}+1 \mathrm{~g} / \mathrm{l}$ moringa leaf powder that gave an opposite trend by reducing this component to the minimum values in the two seasons. This may be the direct reason for the excellence of such combination over all other treatments.

Similar observations were also elicited by El-Sayed et al. (2008) on Tifway turfgrass and Emmanuel et al. (2011) on maize.

From the foregoing, it can be concluded that fertigation seashore paspalum (Paspalum vaginatum Swartz) plants grown in sand and 
Table 7. Effect of fertilization treatments on pigments content $(\mathrm{mg} / \mathrm{g} \mathrm{f.w.})$ in the leaves of Paspalum vaginatum Swartz plants during 2013 and 2014 seasons.

\begin{tabular}{|c|c|c|c|c|c|c|}
\hline \multirow{2}{*}{ Treatments } & \multicolumn{2}{|c|}{ Chlorophyll (a) } & \multicolumn{2}{|c|}{ Chlorophyll (b) } & \multicolumn{2}{|c|}{ Carotenoids } \\
\hline & 2013 & 2014 & 2013 & 2014 & 2013 & 2014 \\
\hline Control & $0.765 \mathrm{~d}$ & $0.806 \mathrm{~d}$ & $0.359 \mathrm{e}$ & $0.376 \mathrm{f}$ & $0.241 \mathrm{~d}$ & $0.255 \mathrm{e}$ \\
\hline $\mathrm{HA}$ at $20 \mathrm{ml} / \mathrm{l}(\mathrm{A})$ & $0.912 b$ & $0.959 b$ & $0.365 \mathrm{c}$ & $0.669 \mathrm{~cd}$ & $0.432 \mathrm{bc}$ & $0.414 b c$ \\
\hline DP at $1 \mathrm{~g} / \mathrm{l}(\mathrm{B})$ & $0.815 \mathrm{c}$ & $0.858 \mathrm{c}$ & $0.417 \mathrm{~d}$ & $0.440 \mathrm{e}$ & $0.281 \mathrm{~d}$ & $0.306 \mathrm{~d}$ \\
\hline MLP at $1 \mathrm{~g} / \mathrm{l}$ ( C ) & $0.969 \mathrm{ab}$ & $1.021 \mathrm{ab}$ & $0.648 \mathrm{c}$ & $0.683 \mathrm{c}$ & $0.434 \mathrm{bc}$ & $0.421 b c$ \\
\hline CCF at 1 g/l (D) & $0.829 \mathrm{c}$ & $0.875 \mathrm{c}$ & $0.565 \mathrm{c}$ & $0.601 d$ & $0.373 \mathrm{c}$ & $0.380 \mathrm{c}$ \\
\hline $\mathbf{A}+\mathbf{B}$ & $0.933 b$ & $0.987 b$ & $0.658 \mathrm{c}$ & $0.698 \mathrm{c}$ & $0.445 b$ & $0.469 b$ \\
\hline $\mathbf{A}+\mathbf{C}$ & $1.031 \mathrm{a}$ & $1.086 \mathrm{a}$ & $0.797 \mathrm{a}$ & $0.840 \mathrm{a}$ & $0.536 \mathrm{a}$ & $0.567 \mathrm{a}$ \\
\hline $\mathbf{A}+\mathbf{D}$ & $0.973 \mathrm{ab}$ & $1.027 \mathrm{ab}$ & $0.721 \mathrm{~b}$ & $0.797 \mathrm{~b}$ & $0.463 b$ & $0.501 \mathrm{ab}$ \\
\hline
\end{tabular}

- HA = humic acid, DP $=$ diatomite powder, MLP $=$ moringa leaf powder and CCF $=$ commercial complete fertilizer.

- Means within a column having the same letters are not significantly different according to Duncan's Multiple Range Test (DMRT) at $5 \%$ level.

Table 8. Effect of fertilization treatments on nitrogen, phosphorus and potassium $\%$ in the leaves of Paspalum vaginatum Swartz plants during 2013 and 2014 seasons.

\begin{tabular}{|c|c|c|c|c|c|c|}
\hline \multirow{2}{*}{ Treatments } & \multicolumn{2}{|c|}{$N(\%)$} & \multicolumn{2}{|c|}{ P (\%) } & \multicolumn{2}{|c|}{ K (\%) } \\
\hline & 2013 & 2014 & 2013 & 2014 & 2013 & 2014 \\
\hline Control & $1.31 \mathrm{c}$ & $1.17 \mathrm{~d}$ & $0.09 \mathrm{c}$ & $0.09 \mathrm{c}$ & $1.09 \mathrm{~d}$ & $1.15 \mathrm{~d}$ \\
\hline $\mathrm{HA}$ at $20 \mathrm{ml} / \mathrm{l}(\mathrm{A})$ & $1.87 \mathrm{~b}$ & $1.90 \mathrm{bc}$ & $0.18 b$ & $0.14 \mathrm{~b}$ & $1.33 b c$ & $1.41 \mathrm{c}$ \\
\hline DP at $1 \mathrm{~g} / \mathrm{l}(\mathrm{B})$ & $1.41 \mathrm{c}$ & $1.47 \mathrm{~cd}$ & $0.11 b c$ & $0.10 \mathrm{c}$ & $1.17 \mathrm{~cd}$ & $1.28 \mathrm{~cd}$ \\
\hline MLP at $1 \mathrm{~g} / \mathrm{l}$ ( C ) & $1.60 \mathrm{bc}$ & $1.78 \mathrm{c}$ & $0.18 \mathrm{~b}$ & $0.16 \mathrm{~b}$ & $1.22 \mathrm{c}$ & $1.32 \mathrm{c}$ \\
\hline CCF at $1 \mathrm{~g} / \mathrm{l}$ (D) & $1.89 \mathrm{~b}$ & $2.04 \mathrm{~b}$ & $0.18 b$ & $0.18 \mathrm{ab}$ & $1.26 \mathrm{c}$ & $1.36 \mathrm{c}$ \\
\hline $\mathbf{A}+\mathbf{B}$ & $2.13 \mathrm{ab}$ & $2.10 \mathrm{~b}$ & $0.21 \mathrm{ab}$ & $0.21 \mathrm{a}$ & $1.50 \mathrm{~b}$ & $1.62 \mathrm{~b}$ \\
\hline $\mathbf{A}+\mathbf{C}$ & $2.41 \mathrm{a}$ & $2.63 a$ & $0.29 \mathrm{a}$ & $0.25 \mathrm{a}$ & $1.76 \mathrm{a}$ & $1.90 \mathrm{a}$ \\
\hline$\underline{A}+\mathbf{D}$ & $2.23 \mathrm{a}$ & $2.38 \mathrm{ab}$ & $0.24 \mathrm{a}$ & $0.23 \mathrm{a}$ & $1.59 \mathrm{~b}$ & $1.70 \mathrm{~b}$ \\
\hline
\end{tabular}

- HA = humic acid, DP = diatomite powder, MLP = moringa leaf powder and CCF $=$ commercial complete fertilizer.

- Means within a column having the same letters are not significantly different according to Duncan's Multiple Range Test (DMRT) at $5 \%$ level.

Table 9. Effect of fertilization treatments on total soluble sugars, indoles and phenols in the leaves of Paspalum vaginatum Swartz plants during 2013 and 2014 seasons.

\begin{tabular}{|c|c|c|c|c|c|c|}
\hline \multirow[t]{2}{*}{ Treatments } & \multicolumn{2}{|c|}{$\begin{array}{c}\text { Total soluble sugars } \\
(\%)\end{array}$} & \multicolumn{2}{|c|}{$\begin{array}{c}\text { Total indoles } \\
\text { (mg/100 g f.w.) }\end{array}$} & \multicolumn{2}{|c|}{$\begin{array}{l}\text { Total phenoles } \\
\text { (mg/100 g f.w.) }\end{array}$} \\
\hline & 2013 & 2014 & 2013 & 2014 & 2013 & 2014 \\
\hline Control & $7.12 \mathrm{e}$ & $7.70 \mathrm{~d}$ & $0.001 \mathrm{~d}$ & $0.001 \mathrm{c}$ & $0.020 \mathrm{~b}$ & $0.021 \mathrm{~b}$ \\
\hline $\mathrm{HA}$ at $20 \mathrm{ml} / \mathrm{l}(\mathrm{A})$ & $9.47 \mathrm{bc}$ & $10.23 b$ & $0.003 \mathrm{c}$ & $0.002 b c$ & $0.021 b$ & $0.021 b$ \\
\hline DP at 1 g/l (B) & $8.00 \mathrm{~d}$ & $8.76 \mathrm{c}$ & $0.001 \mathrm{~d}$ & $0.001 \mathrm{c}$ & $0.021 b$ & $0.020 \mathrm{~b}$ \\
\hline MLP at $1 \mathrm{~g} / \mathrm{l}$ ( C ) & $9.33 \mathrm{c}$ & $9.40 \mathrm{bc}$ & $0.005 \mathrm{ab}$ & $0.003 b$ & $0.020 \mathrm{~b}$ & $0.020 \mathrm{~b}$ \\
\hline CCF at $1 \mathrm{~g} / \mathbf{1}$ (D) & $9.26 \mathrm{c}$ & $10.00 \mathrm{~b}$ & $0.004 b$ & $0.003 b$ & $0.029 \mathrm{a}$ & $0.023 \mathrm{a}$ \\
\hline $\mathbf{A}+\mathbf{B}$ & $9.56 \mathrm{bc}$ & $10.33 \mathrm{ab}$ & $0.003 \mathrm{c}$ & $0.003 b$ & $0.020 \mathrm{~b}$ & $0.021 b$ \\
\hline $\mathbf{A}+\mathbf{C}$ & $10.49 \mathrm{a}$ & $10.96 \mathrm{a}$ & $0.006 \mathrm{a}$ & $0.005 \mathrm{a}$ & $0.016 \mathrm{c}$ & $0.015 \mathrm{c}$ \\
\hline $\mathbf{A}+\mathbf{D}$ & $9.88 \mathrm{~b}$ & $10.50 \mathrm{ab}$ & $0.005 \mathrm{ab}$ & $0.004 \mathrm{ab}$ & $0.023 \mathrm{ab}$ & $0.023 \mathrm{a}$ \\
\hline
\end{tabular}




\section{S.M. Shahin et al.}

clay mixture $(1: 1, \mathrm{v} / \mathrm{v})$ with HA liquid fertilizer at $20 \mathrm{ml} / 1$ + the dry leaf powder of moringa at 1 $\mathrm{g} / \mathrm{l}$, five times with one month interval may be one of the best practical way to establish the best lawn of such grass.

\section{REFERENCES}

Abdel-Fattah, Gehan, H.; Shahin, S.M. and ElSayed, A. Boshra, (2008). The role of humic acid in reducing the harmful effect of irrigation with saline water on Tifway turf. J. Biol. Chem. \& Environ. Sci., 3(1):75-89.

A.O.A.C. (1980). Association of Official Agricultural Chemists "Official Methods of Analysis of the Association of Official Agricultural Chemists". $15^{\text {th }}$ Ed., Arlington, Virginia 22201:877-878.

Cottenie, A.; Verloo, M.; Kiekan, L.; Velghe, G. and Comerlynck, R. (1982). Chemical Analysis of Plants and Soils. Laboratory of Analytical and Agrochemistry. State Univ., Ghent-Belgium, p. 45 .

Dorer, S.P. and Peacock, C.H. (1997). The effect of humate and organic fertilizer on establishment and nutrition of creeping bentgrass putting greens. Inter. Turfgrass Soci. Res. J., 8:437-443.

Dubois, M.; Smith, F.; Illes, K.A.; Hamilton, J.K. and Rebers, P.A. (1956). Colorimetric mehod for determination of sugars and related substances. Ann. Chem., 28(3):350-356.

Duncan, D.B. (1955). Multiple range and multiple F., Tests J. biometrics ,11:1- 42.

El-Sayed, Boshra A. (2012). Improving growth and quality of seashore paspalum turf by actosol and oligo-X. J. Biol. Chem. \& Environ. Sci., 7(2):77-87.

El-Sayed, Boshra, A.; Abdel-Fattah, Gehan, H.; and El-Shal, S.A. (2008). Improvement of growth and quality of Tifway sod by actosol and biofertilizers. J. Biol. Chem. \& Environ. Sci., 3(1):91102.
Emmanuel, S.A.; Zaku, S.G.; Adedirin, S.O.; Muazu, Tafida and Thomas, S.A. (2011). Moringa oliefera seed-cake, alternative biodegradable and biocompatibility organic fertilizer for modern farming. Agric. \& Bio. J. N. Amer., 2(9):12891292.

Higa, T. and Wididana, G.N. (1991). Changes in the soil microflora induced by effective microorganisms. Proc. the $1^{\text {st }}$ Inter. Conf. Kyusei Nature Farming, US Dept. Agric., Washington D.C., USA, p. 153-162.

Huxley, A.; Griffiths, M. and Levy, M. (1992). The New Royal Hort. Society Dictionary of Gardening. The Stockton Press, 257 Park Avenue South, New York, N. Y. 10010, USA, Vol. 3, 790 pp.

Jackson, M.L. (1973). Soil Chemical Analysis. Prentice-Hall of India Private Limited M-97, New Delhi, India, 498 pp.

Khenizy, Soad, A.M.; Abdel-Moneim, Azza, M. and Abdel-Fattah, Gehan, H. (2014). Effect of natural extracts on vase life of Gypsophila cut flowers. Scientific J. Flowers \& Ornam. Plants, 1(1):1-16.

Kozlowski, T.T. and Davies, W.J. (1975). Control of water balance in transplanted trees. J. Arboriculture, 1(1):1-10.

Mahdi, M.Z. (1953). The Influence of Management on Botanical Composition and Quality of Turf. Ph.D. Thesis, Fac. Agric., California Univ., Los Angeles, USA.

Mead, R.; Curnow, R.N. and Harted, A.M. (1993). Statistical Methods in Agriculture and Experimental Biology. $2^{\text {nd }}$ Ed., Chapman \& Hall Ltd., London, 335 pp.

Morton, J.F. (1974). Salt tolerant silt grass (Paspalum vaginatum Swartz). Proceeding of the Florida State, Hort. Sci., Miami Univ., USA, 86:482-490.

Moyo, B.; Masika, P.J.; Hugo, A. and Muchenje, V. (2011). Nutritional characterization of moringa (Moringa 
oleifera Lam.) leaves. African J. of BioTech., 10(60):12925-12933.

Nathan, J.S. and Morgan, L. Vis. (2009). Use of diatoms to assess agricultural and cool mining impact on streams and multiassemblage case study. J. of $\mathrm{N}$. American Benthological Soci., 28(3):659-675.

Peacock, C.H.; Daniel, P. F. and Dudek, A. E. (1985). A comparison of sod type and fertilization during turf establishment. HortSci., 20(1):108-109.

Pregl, F. (1945). Quantitative Organic Micro-Analysis, $4^{\text {th }}$ Ed. J \& A., churchill, Ltd., London, p. 203-209.

Price, M.L. (2007). The moringa tree. ECHO Technical Note. 17391 Durrance Road, North Fort Myers, FL 33917, USA, P.119. Web site: http://www.echonet.org.
Saric, M.; Kastrori, R.; Curic, R.; Cupina T. and Geric, I. (1967). Chlorophyll Determination. Univ U Noven Sadu Parktikum is Fiziologize Biljaka, Beogard, Haucna, Anjige, p. 215.

SAS, Institute Program (1994). SAS/STAT User's Guide, Statistics. Vers. 6.04, $4^{\text {th }}$ Ed., SAS. Institute Inc. Cary, N.C., USA.

William, M.; Chichlilo, P.; Clifford, P.A. and Reynolds, M. (1965). Official Methods of Analysis of the Association of Official Agriculture Chemists, $10^{\text {th }}$ Ed., Washington D.C. 20044:52-55.

Youssef, Hanan, M.A. and El-Sayed, Boshra, A. (2012). Studying the effect of compost and some natural extracts on growth and quality of Euonymus japonicus, Thunb., cv. Aureus plant. J. Biol Chem. \& Environ. Sci., 8(1):33-42.

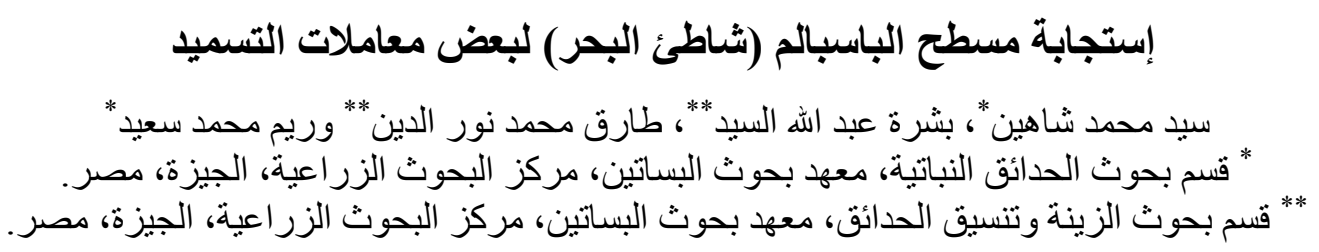

أجريت هذه التجربة بالحقل المكثوف بالمزرعة التجريبية لمعهد بحوث البساتين، مركز البحوث الزر اعية، الجيزة،

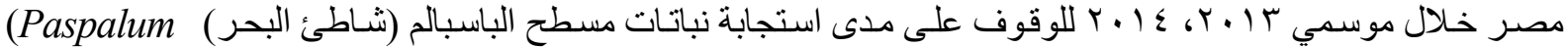
(vaginatum Swartz)

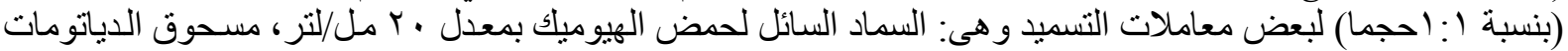

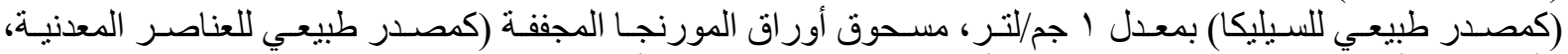

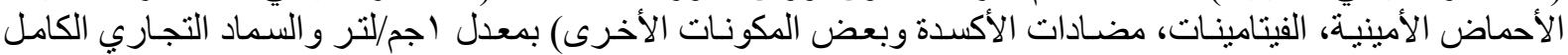

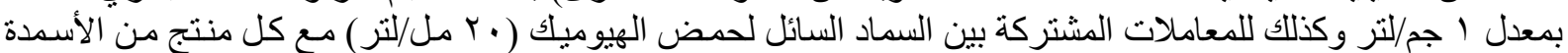

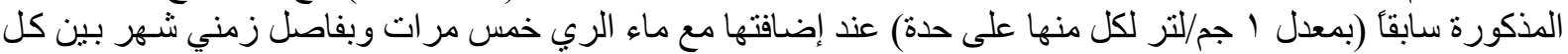
مرتين.

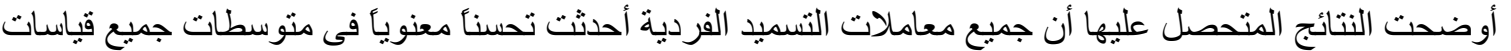

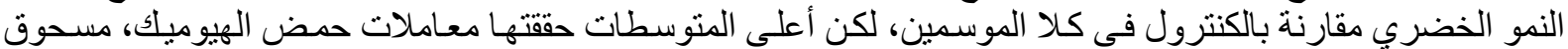

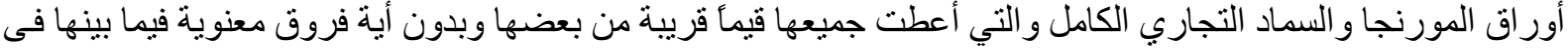

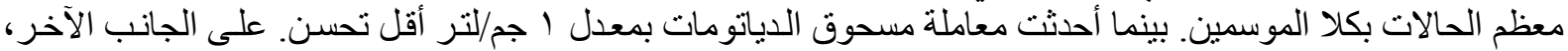

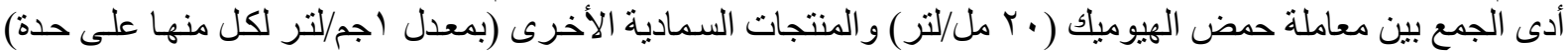

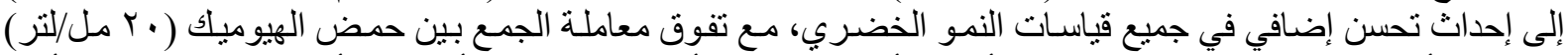

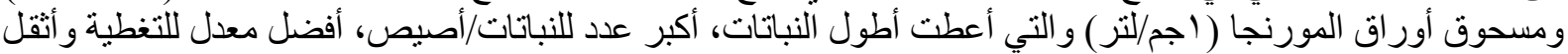

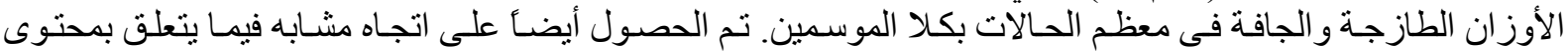

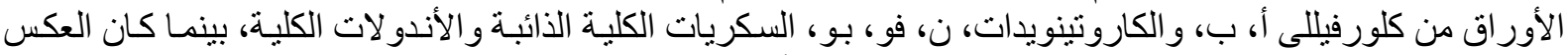

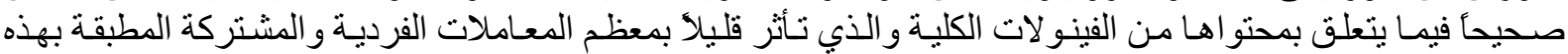

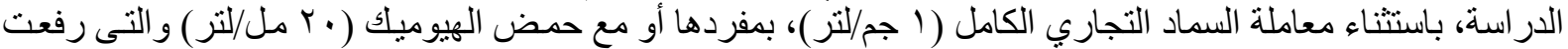

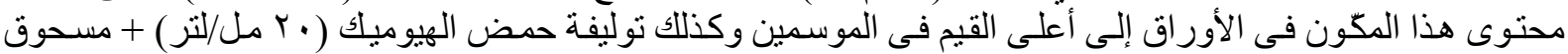




\section{S.M. Shahin et al.}

أور اق المورنجا ( جم/لتر) و التي أعطت إتجاهـأ معاكسأ بخفض محتوى هذا المكون إلى أدنى القيم على الإطلاق بكلا الموسمين.

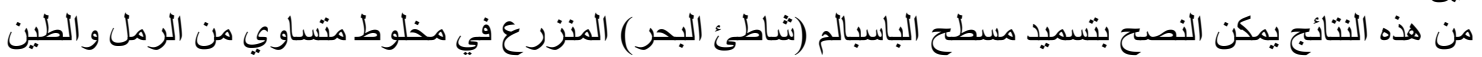

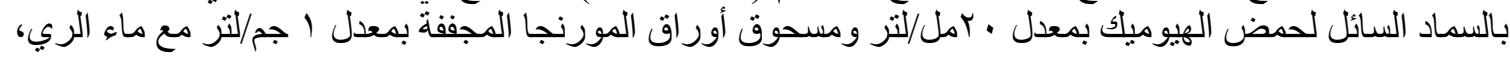

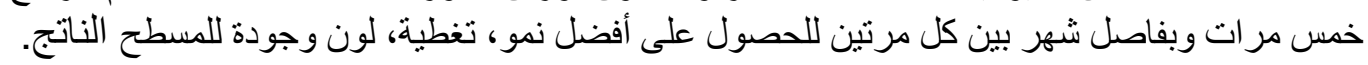

